\title{
Encyclopedia of Politics of the American West
}

\section{Federal Energy Regulatory Commission, U.S.}

Contributors: Steven L. Danver

Print Pub. Date: 2013

Online Pub. Date: May 21, 2013

Print ISBN: 9781608719099

Online ISBN: 9781452276076

DOI: $10.4135 / 9781452276076$

Print pages: $325-326$

This PDF has been generated from SAGE knowledge. Please note that the pagination of the online version will vary from the pagination of the print book. 


\subsection{5/9781452276076.n164}

Initial federal legal authority to regulate oil pipelines was given to the Interstate Commerce Commission in 1906 (Pub. L. 59-337). Following seven decades of governmental regulatory policymaking development and evolution, the Federal Energy Regulatory Commission (FERC) was established in 1977 within the newly created Department of Energy (DOE) (Pub. L. 95-91). FERC is an independent agency within DOE consisting of five presidentially appointed members subject to Senate confirmation. Its primary responsibilities include regulating the prices and interstate transmission of electricity, natural gas, and oil. Additional responsibilities include reviewing proposals to build and locate liquefied natural gas terminals and interstate natural gas pipelines as well as licensing hydropower projects along with regulating mergers and securities acquisitions under the 1938 Natural Gas Act (Pub. L. 75-688) and 1935 Federal Power Act (Pub. L. 74-333).

Legislation in 1978 (Pub. L. 95-617) saw unification of intrastate and interstate natural gas markets, and subsequent years saw FERC move toward gradual energy market deregulation during the Reagan administration. FERC Order 436 (1985) required natural gas pipelines to provide open access to transportation services enabling consumers to negotiate prices directly with producers and contract separately for transportation. FERC Order 636 (1992) mandated unbundling of sales services from transportation services giving customers full choice of providers and opening these markets to competition.

This deregulation continued during both Bush administrations and the Clinton administration. FERC Order 888 (1996) required electricity transmission owners purchasing transmission service to provide open access to their own facilities for others seeking comparable access to such services, sought to ensure potential electricity suppliers had equal access to the market, and encouraged creation of a separate price exchange to reveal market-clearing prices for electricity in the new competitive market.

The 2005 Energy Policy Act (Pub. L. 109-58) produced the most significant changes in FERC authority since the Federal Power and Natural Gas Acts. Powers granted to FERC by this legislation included the following: 
FERC adopted a final rule on February 15, 2007, to ensure transmission service is provided on a nondiscriminatory just, and reasonable basis and provide for more effective grid regulation and operational transparency. FERC issued Order 719 on October 17, 2008, to finalize regulations designed to strengthen and improve the operational competitiveness of organized wholesale electricity markets by using demand response, encouraging long-term power contracts, strengthening the role of market monitors, and enhancing the responsiveness of regional transmission organizations and independent system operators.

Increasing population in the western United States will lead to a continued increase in the demand for geographically and geologically dispersed domestic energy resources. The [p. $325 \downarrow$ ] likelihood that the United States will seek to develop and exploit previously untapped natural resources, such as oil and natural gas in the western United States and the Keystone XL pipeline project originating in Alberta, Canada, in order to reduce reliance on foreign energy sources, will further increase the already important role FERC plays in western states' economic and political trends and developments. FERC will remain a critical and controversial player in developing and shaping U.S. governmental energy policy and commercial energy sector development for the foreseeable future.

Albert T. Chapman

\subsection{5/9781452276076.n164}

See also

Further Readings

Cohen, Leonard L. "Eighty Years of US Petroleum Pipeline Regulation ." The Journal of Transport History vol. 9 , no. 2 (September 1988): pp. 149-69.

Haskell, Mark R., and Levi McAllister. "Policing Market Manipulation: A Review of Evolving Federal Energy Regulatory Commission Policy." The Electricity Journal vol. 24 , no. 2 (March 2011): pp. 34-43. http://dx.doi.org/10.1016/j.tej.2011.01.011 
U.S. Senate Committee on Energy and Natural Resources . Electricity Proposals and Electric Transmission and Reliability Enhancement Act of 2003 . Washington, DC: Government Printing Office, 2003. 